\title{
A 900-YEARS LARCH CHRONOLOGY FOR NORTH-WESTERN SIBERIA ON THE BASES OF ARCHAEOLOGICAL WOOD OF THE UST-VOYKAR SETTLEMENT
}

\author{
MARINA GURSKAYA \\ Institute of Plant and Animal Ecology, \\ 8 Marta 202, 620144 Yekaterinburg, Russia
}

Received 2 July 2007

Accepted 19 September 2007

\begin{abstract}
During 2003-2006 summer excavation seasons of the Ust-Voykar settlement $\left(65^{\circ} 40^{\prime} \mathrm{N}\right.$, $64^{\circ} 30^{\prime}$ E) located in northwestern Siberia on the left bank of Gornaya Ob river, 121 samples of larch were collected. Living trees collected nearby were used to cross-date settlement construction. On the basis of living larch trees a 446 year (1554-1999) chronology has been constructed. Calendar dates for 101 samples of archaeological wood were established by cross-dating. Together, the living and archeological material result in a 903 year long chronology. This chronology shows similar variations as the Yamal and Polar Ural chronologies and provides new material that can be included in future climatic reconstructions.
\end{abstract}

Keywords: archaeological wood, dendrochronology, Larix sibirica, North-West Siberia, the UstVoykar settlement.

\section{INTRODUCTION}

Building long chronologies is a top priority of modern dendrochronology. In polar and sub-polar regions this task was successfully achieved based on subfossil wood preserved in permafrost. However, so far, no long chronologies have been constructed for the northern taiga in western Siberia. This has several reasons. One of them is the fast decay and hence poor preservation of wood near the ground surface. Another reason is short lifespan of trees in this area compared with forest-tundra ecosystems where trees may live to be 800 years old (Shiyatov, 1986).

Using wood from archaeological, historical, and ethnographical wooden monuments it is however possible to build tree-ring chronologies. In North-Western Siberia many archaeological and historical sites were discovered (Shiyatov et al., 2005). Archaeological monuments from the northern taiga of Western Siberia represent a unique source of timber wood. V. Goryachev et al. (2002) studied historical settlement Nadym, located in forest-tundra in Western Siberia. They found a great number of well preserved trees and shrubs, which were used in constructions. Timber from these settlements was successfully used to date building periods. These works revealed that long tree-ring chronologies could be developed from treering series constructed from historical timbers from northern settlements. The wooden remains of archaeological settlements were also successfully used for reconstruction of temperature conditions of the Nadym settlement (Goryachev, 2003).

However, there are a limited number of long tree-ring chronologies from the northern part of Western Siberia. Most of them are derived from settlements located north of the Polar circle. Archaeological timber, recovered from high latitude settlements especially those in the Russian North, are a great source of material for developing long tree-ring chronologies. The subject of this paper, the Voykar settlement from North-Western Siberia, supplies one such chronology.

The study's aims were to develop a tree-ring chronology based on living larch trees, date archeological material and develop a long continuous chronology. 


\section{THE UST-VOYKAR SETTLEMENT}

The Voykar settlement, situated on the west bend of the Gornaya $\mathrm{Ob}$ River along the north-eastern coast of Voykar lake (Fig. 1; 65 $40^{\prime} \mathrm{N}, 64^{\circ} 30^{\prime} \mathrm{E}$ ), is one of the largest and best-known settlements of the $16^{\text {th }}-19^{\text {th }}$ centuries. Voykar is an exceptional settlement because of its location on the crossroads between the Russian West, the Ural region and North, East and South Siberia. The main migratory flows passed through Voykar. There are various myths and legends attached to the historical events that happened in this settlement. It was a trade centre for the native "Ostyak" and "Samoed" tribes from the vast territory of Siberia and a centre for the collection of tribute by the Russian Governor. The first written record mentioning the settlement dates to the end of the $16^{\text {th }}$ and the beginning of the $17^{\text {th }}$ century (a letter of $\mathrm{AD} 1601$ describes a siege of the town of Berezovo in AD 1595). Besides this letter, there are census records from the $18^{\text {th }}-19^{\text {th }}$ centuries. These records show that the Voykar settlement was a well-developed and flourishing town as far back as the $17^{\text {th }}-18^{\text {th }}$ centuries, with the town only being abandoned at the beginning of $20^{\text {th }}$ century (Brusnicyna, 2003). Today, the settlement is completely overgrown by grass and there are no accurate dates for its foundation or rebuilding phases. In 2003, the Yamal Archaeological Expedition carried out an excavation at this place. At the beginning of the excavation, the site was approximately a $11-\mathrm{m}$ high by $200-300 \mathrm{~m}$ diameter mound. The expedition identified a large number of construction timbers from which larch samples were taken for tree-ring analysis.

\section{MATERIALS AND METHODS}

\section{Samples}

\section{Archaeological wood}

During four years of excavations 15 wooden complexes were found. Most of them represent houses, fences and internal floors. Siberian spruce is main tree species used to build most. Approximately 121 cross-sections of larch were collected from 8 of Voykar's constructions and isolated logs during the excavation seasons. Most of the samples were taken from house's main walls, fences, and planking. The timbers were all well preserved in the permafrost. Bark rings were present in most samples, allowing precise identification of felling dates. All constructions were located at different heights on different parts of the Voykar hill.

\section{Living trees}

The spruce (Picea obovata Ledeb.) grows immediately surrounding the excavation site at a distance of 200-300 $\mathrm{m}$. This forest was established in the middle of the $19^{\text {th }}$ century. Larch (Larix sibirica Ledeb.) forests are found approximately $3-5 \mathrm{~km}$ away. Old Siberian pines (Pinus sibirica Du Tour) grow on waterlogged sites together with larch. Cores from living larch were collected during the summer 2000 in two places near Voykar Sor Lake. One site is south bank of the Lake, where 14 trees (termed the LVS chronology), growing in mixed larchpine open forest with wild rosemary, sphagnum and pleu-

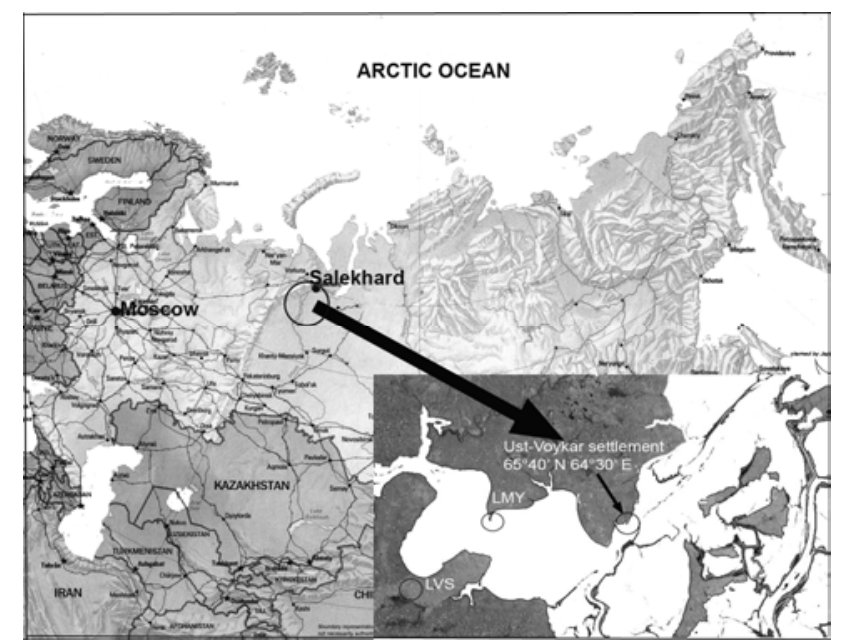

Fig. 1. Research area.

rotium, were selected. A second site was located on a long peninsula on the northern part of the lake. Here larch grows together with spruce. We collected 37 cores (termed the LMY chronology). These two chronologies were also merged into one long chronology spanning 1554-1999.

\section{Methods}

The number of tree rings in each cross section varied from 30 to 340 . Samples, which have more than 50 tree rings, were selected for dating. It was possible to crossdate most of the samples found during the four years of our excavations. Dating of wood remains was accomplished using standard methods (Kolchin, 1963; Baillie, 1982; Eckstein et al., 1984).

Samples were "polished" using a razor-blade and measured along two radii. Samples were dated using two programs: CATRAS (Aniol, 1983) and TSAP software (Rinn, 1996). COFECHA program provided quality control for the calendar dates. The ARSTAN double detrending method, with a negative-exponential fit followed by a 128 year spline was used to remove age-related growth trends from living trees and archaeological timbers (Holmes, 1983; Cook and Holmes 1997). Detrended series were averaged into a mean chronology.

\section{RESULTS}

\section{The statistical characteristics of the chronologies}

\section{Living trees}

Cores of living trees were used to construct two calendar dated larch chronologies: one was 455 years-long and the other 267 year long. These two chronologies have the similar statistical characteristics (Table 1). The mean tree ring width of the individual series varies from 0.3 up to $1.3 \mathrm{~mm}$, with an average of $0.6 \mathrm{~mm}$. Some series have missing rings, but the quantity of missing rings does not exceed $1 \%$. Trees with narrower rings have more missing rings than trees with wide annual rings. Agreement with the theoretical population chronology and the average correlation between series are also high for both chronologies (Wigley et al. 1984). 
Table 1. Statistical characteristics of larch tree ring chronologies.

\begin{tabular}{|c|c|c|c|c|c|c|c|}
\hline 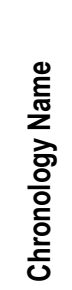 & 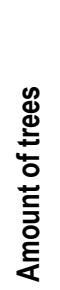 & 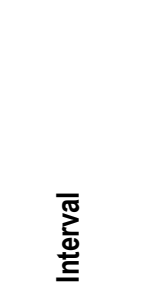 & 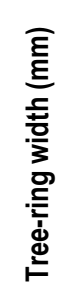 & $\begin{array}{l}\text { 을 } \\
\frac{\pi}{3} \\
\frac{0}{0} \\
\frac{0}{0} \\
\frac{\pi}{0} \\
\frac{0}{0} \\
\text { के }\end{array}$ & 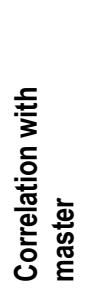 & 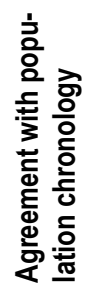 & 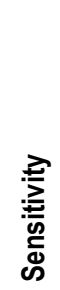 \\
\hline$\overline{L M Y}$ & 37 & $1541-1996$ & 0.67 & 0.39 & $\overline{0.66}$ & 0.90 & 0.42 \\
\hline LVS & 14 & $1732-1999$ & 0.60 & 0.37 & 0.69 & 0.87 & 0.33 \\
\hline
\end{tabular}

Other important characteristics for tree-ring chronologies include the standard deviation and the coefficient of sensitivity. The standard deviation quantifies the amplitude of variability of tree ring thickness. As a general rule, a standard deviation greater than 0.2 specifies heterogeneity of ring-width, and is suggestive for environmental sensitivity (Vaganov et al., 1996). The standard deviation for both chronologies is above 0.35 and therefore indicates great potential to use the investigated chronologies for reconstruction of climatic factors. The climatic potential is also suggested by a high coefficient of sensitivity.

Both of these chronologies were used to date archaeological samples and "floating" chronologies from the UstVoykar settlement.

\section{Archaeological samples}

Most constructions of the monument contained both larch and spruce. Samples of other species such as birch or Siberian pine were seldom employed. Only part of the larch samples (46) were taken from constructions consisting solely of larch. This species was used for main walls and floors in houses in the Ust-Voykar settlement. Walls of buildings have few logs, because only 1-3 joists per floor were generally preserved from houses. Other samples (75 pieces) were lying around or inside constructions or in fences. These samples were used for settlement cross dating and development of a long tree ring chronology.

\section{Ust-Voykar structures investigated}

In the following section we briefly describe the structures investigated.

Construction 4. This construction, located on the top of excavation site, has three well preserved five-meter logs from a floor joist. All three samples, taken from this construction were larch containing between 65 to 92 rings. The tree ring width variations are well synchronized with each other. Outermost rings appeared completely formed, suggesting that trees from this construction were cut between August and May.

Construction 6. Near construction 4 , the northern wall of construction 6 was opened. Two logs taken from this construction are larch. They contain 106 and 126 rings and cross-date well with each other. The last ring is completely formed, hence, the trees used in this construction, have been felled during the autumn-winter period.
Construction 8. This construction is found below constructions 4 and 6. Disks from 12 larch logs were collected, with all samples suitable for analysis. Eight samples are characterized by completely formed latewood in the outermost ring. The other samples have only early wood, with no indication for latewood in the outermost ring. All 12 samples were again easily cross-dated due to the synchronous variations in tree-ring width. Most samples are dated to 1640 . But two logs, situated inside construction 8 near south wall, were felled in 1672 .

Construction 10. The lower part of the excavation site contained two constructions: 10 and 11. Samples from roof were taken from construction 10. In total, 22 samples were collected, but only, four were larch. These samples were again able to be cross-dated and the outermost ring contained latewood cells.

Construction 11. Construction 11 is situated northerly from construction 10. Eight larch samples were collected. Bark ring is present in all samples and formed completely.

Wedges. Five large wedges up to $0.5 \mathrm{~m}$ high were found in a trench, between the upper and lower part of the excavations. Axe marks were observed on surface of wedges and peripheral rings were not preserved.

Separate logs in the upper part of the trench. In the top part of the excavation trench three larch logs were dug out. Probably, they represent some construction which is situated outside the excavation site. The outermost rings were not formed completely. As only early wood was observed, these trees were cut down during June-July, when formation of the annual ring takes place.

Flooring at beginning of the trench. The flooring was up to $3 \mathrm{~m}$ long and up to $1 \mathrm{~m}$ wide, and consisted of 18 logs. Only nine larch samples were possible to collect. Part of the samples has completely formed outermost rings, while the remainders only have earlywood. Most of the samples cross-dated well with each other.

On the basis of the samples, assembled from different constructions, eight "floating" chronologies were constructed. These "floating" chronologies consisted of between 2 and 12 larch samples. The mean tree ring width of most chronologies is about $0.6 \mathrm{~mm}$. Only one chronology, that from construction 4 , was characterized wide tree rings.

Micro anatomical analysis of the most recent ring structures shows that trees used in the construction of this archaeological monument were felled in different seasons. All the wood used for large constructions such as house walls had completely formed latewood rings under their bark. Thus, the wood for the main walls of the UstVoykar settlement was cut during autumn or winter, between August and May.

All investigated individual series were characterized by average to high standard deviation. Thus, despite of narrow annual rings, their amplitude of variability is great enough for cross-dating and likely climatic analyses. This result is confirmed by the coefficient of sensitivity. The constructed "floating" chronologies are characterized by about average coefficients of sensitivity (mean $=0.3$ ). Chronologies with narrow tree rings are characterized by higher sensitivity compared with chronologies with wide annual ring. The good cross-dating is evident in the gen- 
Table 2. Statistical characteristics of "floating" tree ring chronologies. C-Constructions.

\begin{tabular}{|c|c|c|c|c|c|c|}
\hline 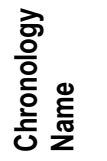 & 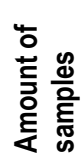 & 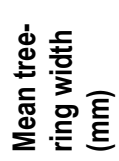 & 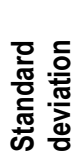 & : & 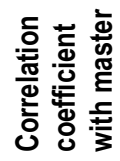 & 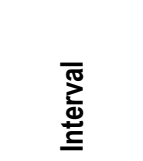 \\
\hline$\overline{\mathrm{C} 6}$ & 2 & 0.67 & 0.41 & 0.28 & 0.37 & $1551-1678$ \\
\hline C4 & 3 & 1.11 & 0.75 & 0.27 & 0.69 & $1555-1647$ \\
\hline $\mathrm{C} 8$ & 12 & 0.73 & 0.36 & 0.28 & 0.61 & $1393-1640$ \\
\hline Logs & 3 & 0.59 & 0.36 & 0.30 & 0.46 & $1409-1564$ \\
\hline wedges & 5 & 0.33 & 0.23 & 0.37 & 0.55 & $1115-1458$ \\
\hline flooring & 9 & 0.48 & 0.25 & 0.29 & 0.47 & $1163-1411$ \\
\hline C10 & 4 & 0.59 & 0.27 & 0.26 & 0.62 & $1128-1314$ \\
\hline C11 & 8 & 0.34 & 0.21 & 0.35 & 0.50 & $1120-1302$ \\
\hline
\end{tabular}

erally high mean correlation coefficients with the master chronology (Table 2).

In general, the statistical characteristics of "floating" chronologies, based upon archaeological wood, are close to those obtained for modern trees. It specifies that larch, used for construction of the settlement, probably grew in similar conditions in the past. Harvest locations could therefore include floodplain, riverside, or waterlogged sites.

\section{Cross dating of archaeological samples}

Calendar dates for tree felling were established with the help of three different software packages: CATRAS, TSAP and COFECHA and the 445 year-long living-tree larch chronology. The t-values computed in CATRAS, ranged from 3.8 up to 22 , with an average of 6.2. TSAP was used to date and graphically check the location of individual series in time. Statistical estimations of dating were provided by COFECHA.

Individual series obtained from each construction, were confidently dated to each other. In the Fig. 2, the temporal positions of the individual tree ring series from the different constructions is shown. In this figure, one or two individual series from each of the above mentioned constructions is shown. The total time intervals established for the eight constructions and the derived "floating" chronologies are specified in Table 2.

In addition to the samples taken from constructions, samples which were located outside of constructions were also calendar dated. These samples were dated using both the living tree chronologies and the calendrically dated archaeological material.

In total, 101 from 121 samples were successfully cross-dated, yielding a dating success rate of $83 \%$. This represents a very successful ratio for dendrochonological dating of an archaeological monument.

The results of dating are shown in Fig. 3. Mass tree felling for settlement construction was carried out at the beginning of the $14^{\text {th }}$ (construction 10 and 11), and the middle of the $15^{\text {th }}$ century (flooring and wedges). Many trees were cut in the middle of the $17^{\text {th }}$ century (constructions 4, 6 and 8). One $\log$, with a felling data of 1887, represents the latest archaeological object investigated. However, this log did not was not part of any settlement structure.

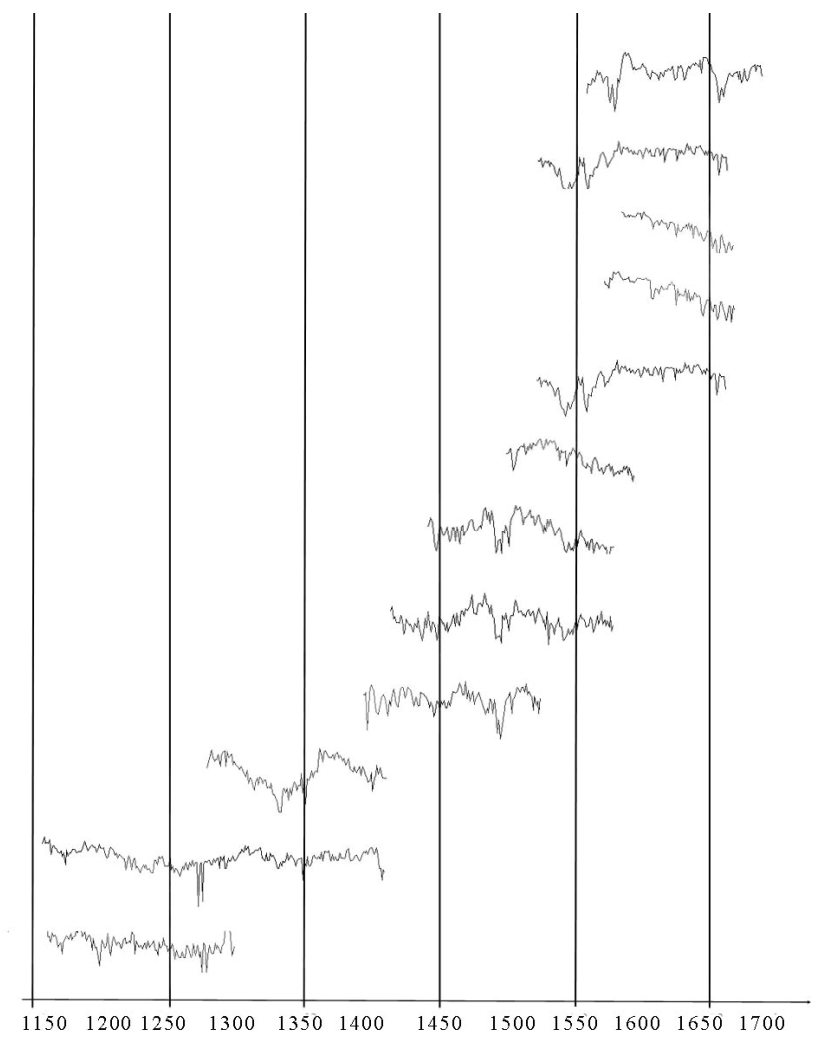

Fig. 2. Dendrochronological dating of some individual series in constructions at the Voykar settlement.

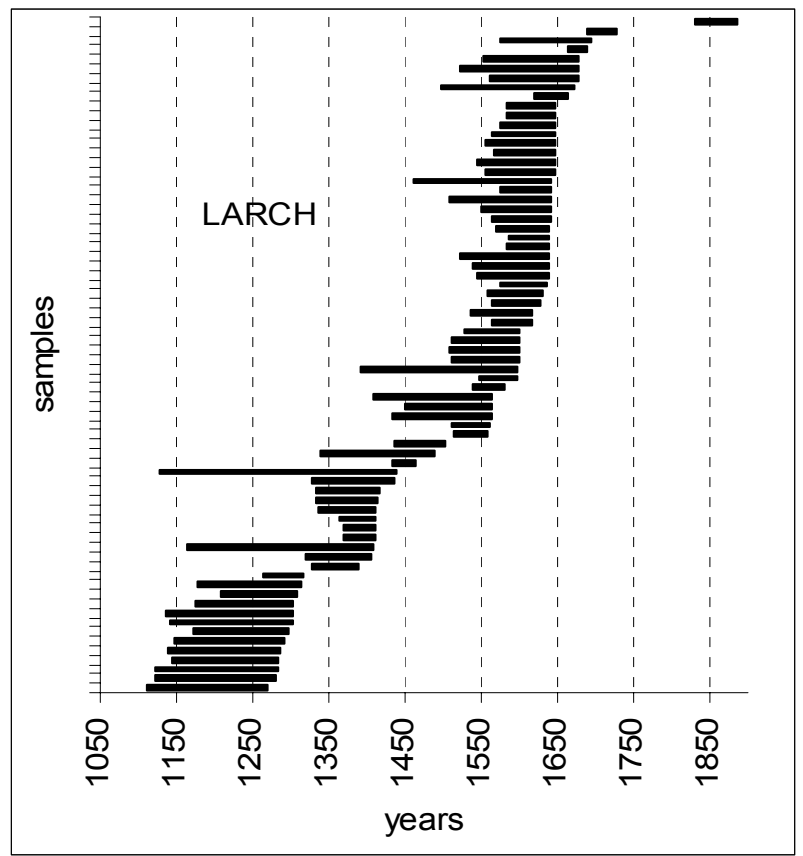

Fig. 3. Life span of trees.

On the basis of all dated samples (101 pieces), an archaeological tree-ring chronology of 597 years (10961693) was constructed. This archaeological chronology was combined with the 443 year long larch chronology derived from living trees. These two chronologies overlap by 140 years. Together, these data resulted in a 903 year 

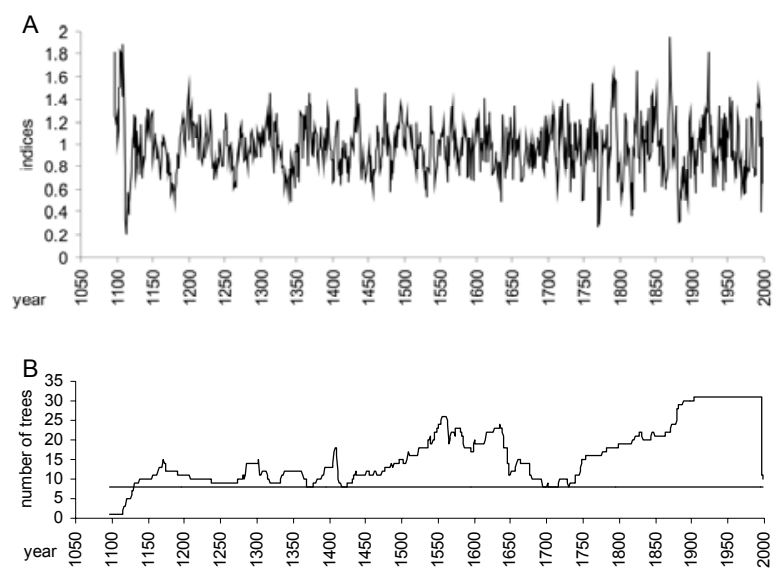

Fig. 4. The 900 year-long Voykar larch chronology. A - tree-ring chronology. B - Amount of trees and Expressed population signal (horizontal line).

long chronology, which is referred to as the Voykar chronology (Fig. 4A). Series which were included in the Voykar chronology are characterized high coherency. Based on the inter-series correlation, eight trees represent an expressed population signal of 0.85 . Accordingly, the Voykar larch chronology provides enough tree samples for most of the 903 years to provide a stable estimate of the mean chronology, which is important for any subsequent climatic reconstruction. (Fig. 4B).

\section{Comparison with Polar Ural and Yamal larch chro- nologies}

One possible way to estimate the tree ring chronology signal is by comparison with other geographically near chronologies. Therefore, the Voykar chronology was compared with the Polar Ural and Yamal larch chronologies.

The Polar Ural chronology, developed by Shiyatov (1993), is 1100 years long. It was built from material sampled along the upper tree line of the Polar Urals 100$150 \mathrm{~km}$ north of Ust Voykar. The 4000 year larch Yamal chronology was built by Hantemirov and Shiyatov (2002). They used subfossil wood and living trees, growing at northern tree line on the southern part of the Yamal peninsula $300 \mathrm{~km}$ north of the Voykar settlement.

The comparison of chronologies using CATRAS t-value shows good level similarity between Voykar and both other chronologies. The t-value between Voykar and Polar Ural chronology is 12.9 and between Voykar and Yamal 14.6.

Running correlation coefficients are always positive and range between 0.47 and 0.80 (Fig. 5). The chronology portion containing only living trees (1690-1999) has average correlation coefficient of about 0.60 . Other parts of chronology, consisting of both modern living larch and archaeological wood (1550-1690 period), is characterized by a high correlation with the Polar Ural and average correlation with the Yamal chronologies. The period with the highest coefficient of correlation is between 1350 to 1550 when correlations with both northern chronologies are between $0.7-0.8$. The period between 1096 to 1350 is

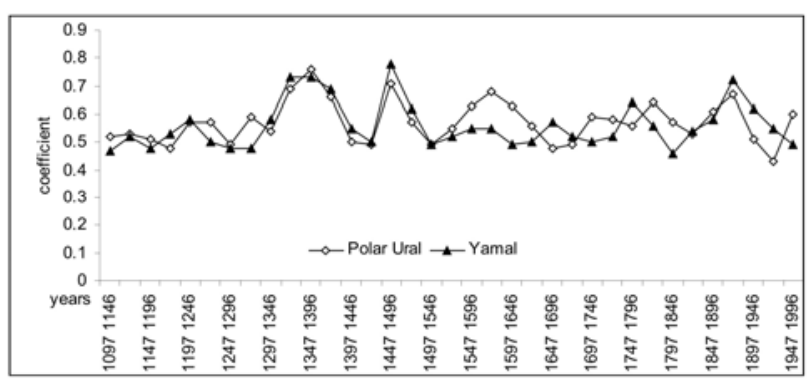

Fig. 5. Running correlation between the Voykar and the Yamal and the Polar Ural larch chronologies.

characterized by average correlation, similar with the correlation obtained with the living trees.

The variability of correlation coefficients during last 900 years may be a result of several factors. One possibility could be the utilization of timber wood from trees, growing north of the settlement, and closer to the Polar Ural Mountains. Other, reasons could include more and less distinct climatic periods.

\section{CONCLUSIONS}

Archaeological wood from the Ust-Voykar settlement was used to build a 903-year-long larch chronology. The sample replication and high correlation between series make this chronology of high enough quality for consideration of possible climatic reconstruction. This chronology is one of the first long tree-ring chronologies for the northern taiga zone of Western Siberia.

The larch tree-ring chronologies Voykar, Yamal and Polar Ural are very similar. It points to dendrochronological homogeneity of the area of the North-Western Siberia. It would be possible to construct a regional larch chronology for North-Western Siberia, but also maybe possible to investigate local climatic variations within this region.

\section{ACKNOWLEDGMENTS}

Financial support of this work was provided by RFBR grant No 05-06-80-233 and DAAD scholarship. The author would like to thank colleagues of Hamburg University, Department of Wood Science division of wood biology Prof. Dr. D. Eckstein, Dr. S. Wrobel, C. Piel and G. Lütje for their considerable help for cross dating of archaeological material. Many thanks to Dr. L.I. Agafonov scientific researcher of dendrochronological laboratory of Institute of Plant and Animal Ecology UD RAS for his kind help with collection of samples of living trees. Hearty thanks to archaeological team of Institute of History and Archaeology UD RAS and specially Dr. N.V. Fedorova and A.G. Brusnicyna for possibility to participate in excavations of the Ust-Voykar settlement and good help with collection of archaeological material.

\section{REFERENCES}

Aniol RW, 1983. Tree-ring analysis using Catras. Dendrochronologia 1: 45-53. 
Baillie MGL, 1982. Tree-ring Dating and Archaeology. Chicago, The University of Chicago Press: $265 \mathrm{pp}$.

Brusnicyna AG, 2003. Goroditsche Ust-Voykarskoe. Nachalo izucheniya (The Voykar settlement. Beginning of the study). Ugry. Materialy VI Sibirskogo simposiuma "Kulturnoe nasledie narodow Zapadnoy Sibiri”. Tobolsk: 45-52 (in Russian).

Cook ER and Holmes RL, 1997. ARSTAN: chronology development. In: Grissino-Mayer HD, Holmes RL and Fritts HC, eds., Documentation to the International Tree-Ring Data Bank Program Library - Version 2.1: 75-87.

Eckstein D, Baillie MGL, and Egger H, 1984. Dendrochronological Dating: Handbooks for Archaeologists No. 2. Strasbourg, European Science Foundation: $56 \mathrm{pp}$.

Goryachev VM, 2003. Ispolzovanie ostatkov drevesiny "Nadymskogo goroditscha" dlya postroenia dlitelnyh khronologii I reconstrukcii temperaturnyh uslovii (Using of timberwood of the "Nadym settlement" for construction of long tree-ring chronology and reconstructins of temperature conditions). In: Ekologia drevnih I sovremennyh obtschestv. Doklady konferencii Vyp.2 Tyumen IPOS SO RAN, 2003 C: 30-33 (in Russian).

Goryachev VM, Goryacheva TA and Kardash OV, 2002. Chronologia "Nadymskogo goroditscha" s pomotschiu drevesno-kolcevogo analisa. (Chronology of the "Nadym settlement" with help of treering analisis). In: Chronologia I stratigrafia archeologicheskih pamjatnikov holocena Zapadnoj Sibiri I sopredelnyh territorij. Materialy nauchnogo seminara 18-19 noyabrya 2001. Tyumen, Institut problem osvoeniya Severa SO RAN: 22-23 (in Russian).

Hantemirov RM and Shiyatov SG, 2002. A continuous multimillennial ring-width chronology in Yamal, northwestern Siberia. Holocene 12(6): 717-726, DOI 10.1191/0959683602hl585rp.
Holmes RL, 1983. Computer-assisted quality control in tree-ring data and measurement. Tree-Ring Bulletin 43: 69-78.

Kolchin BA, 1963. Dendrochronologia Novgoroda. Novye metody v archeologii. (Dendrochronology of Novgorod. New methods in archaeology) Trudy Novgorodskoy archeologicheskoy ekspedicii. M. AN SSSR. No117: T3.

Rinn F, 1996. TSAP - Time Series Analysis and Presentation, Version 3 Reference Manual. Heidelberg: $118 \mathrm{pp}$.

Shiyatov SG, 1986. Dendrochronologiya verchney granicy lesa na Urale (Dendrochronology of upper tree-line on the Ural's). Moscow, Nauka: 136 pp (in Russian).

Shiyatov SG, 1993. The upper timberline dynamics during the last 1100 in the Polar ural Mountains. In: Burhard Frenzel, ed., Oscillations of the Alpine and Polar Tree Limits in the Holocene. Stuttgart; Jena; New-York, Gustav Fisher Verlag: 195-203.

Shiyatov SG, Hantemirov RM, Goryachev VM, Agafonov LI and Gurskaya MA, 2005. Dendrochronologicheskie datirovki archeologicheskih istoricheskih I ethnograficheskih pamyatnikov Zapadnoi Sibiri (Dendrochronological dates of archaeological, historical and ethnographical monuments of Western Siberia). Archeologia i estestvennonauchnye metody. M. Yazyki slavyanskoy kultury: 43-57 (in Russian).

Vaganov EA, Shiyatov SG and Mazepa VS, 1996. Dendroclimaticheskie issledovania $v$ Uralo-sibirskoy Subarktike (Dendroclimatic studies in Ural-Siberian Subarctic). Novosibirsk, Nauka: 246pp (in Rusian).

Wigley TML, Briffa KR and Jones PD 1984. On the average of correlated time series, with applications in dendroclimatol-ogy and hydrometeorology. Journal of Climate and Applied Meteorology 23(2): 201-213, DOI 10.1175/15200450(1984)023<0201:OTAVOC $>2.0$. CO;2. 